\title{
Struktur Populasi Genetik Ayam Hutan Hijau Menggunakan Sekuen Hypervariable 1 D-Loop DNA Mitokondria
}

\section{Genetic Population Structure of Green Jungle Fowls Using D-Loop Hypervariable-1 of Mitochondrial DNA}

\section{Syamsul Arifin Zein* dan Sri Sulandari}

Bidang Zoologi, Pusat Penelitian Biologi-LIPI

Widyasatwaloka Building, Jalan Raya Jakarta Bogor KM 46 Cibinong 16911

E-mail: zein_genetic@yahoo.com*Penulis untuk korespondensi

\begin{abstract}
Thirty-three individuals from four populations of green junglefowl (Gallus varius) were collected throughout Indonesia: 14 from Central Java, 4 from Eastern Java, 3 from Sumbawa island and 12 from Flores island. The mitochondrial DNA D-loop the samples were analysed for sequence diversity. Twenty-five haplotypes with 28 polymorphic sites were identified within the first hypervariable-1 fragment (397 bp) of the D-loop. Fu's Fs value was -25.96 (all samples, $P=0$ ), indicating high genetic diversity and population expansion; a conclusion supported by a neighbor-joining analysis of the haplotypes. Though sample size per population varied between 3 and 14, the Fs values for the four populations, between -2.20 and -10.76 , were all significant $(\mathrm{P}=\mathbf{0})$. Only one haplotype was shared between three populations (Central Java, Sumbawa island, and Flores island) by a total of seven individuals. Within populations, only three haplotypes were shared by three individuals. The remaining haplotypes were unique, indicating genetic differentiation between populations as confirmed by significant pairwise Fst values at $\mathrm{P}=\mathbf{0 . 0 5}$ in four out of the six population pairs (except two pairs of Central Java \& Sumbawa island and Flores island \& Sumbawa island). The diversity pattern observed at the mtDNA of the green junglefowl provides a baseline which may help to understand the recent population expansions of domesticated chickens from multiple centres of domestications. Our observations also suggest careful interpretation of the results of genetic characterization may be needed when applied to the management and conservation of species like the green junglefowl. As in other multiparous birds and mammals with a short reproductive interval, green junglefowl may have established distinct genetic entities in metapopulations across its geographic distribution.
\end{abstract}

Key words: Gallus varius, hypervariable-1, D-Loop, mitochondrial DNA, diversity

Diterima: 08 Juli 2008, disetujui: 27 Oktober 2008

\section{Pendahuluan}

Ayam hutan Hijau (Gallus varius) adalah unggas dari suku Phasianidae, yakni keluarga ayam, puyuh, merak dan sempidan. Ayam hutan hijau merupakan representatif spesies unggas di Indonesia dan habitatnya meliputi hutan primer, hutan sekunder, semak, padang rumput, dan daerah pertanian yang dekat dengan hutan. Distribusi ayam hutan hijau menurut Sibley dan Monroe (1990) dan Oka et al., (2004), meliputi dataran rendah hingga ketinggian $2400 \mathrm{~m}$ di atas permukaan laut di Jawa, Madura, Bawean, Kangean, Bali, Lombok, Sumbawa, Flores, dan Alor serta pulau-pulau kecil di sekitarnya. Wirdateti et al., (2007) mengatakan bahwa akibat pemanfaatan 
dan perusakan hutan telah mengakibatkan banyak jenis satwa liar menuju kepunahan.

Ayam hutan hijau dikenal sebagai sumber tetua untuk menghasilkan ayam bekisar yang merupakan persilangan antara ayam-hutan hijau dengan ayam kampung. Ayam bekisar dikembangkan orang untuk menghasilkan ayam hias yang indah bulunya, terutama untuk mendapatkan ayam dengan kokok yang khas. Karena suaranya, ayam bekisar dapat mencapai harga yang sangat mahal. Bekisar juga menjadi lambang fauna daerah Jawa Timur. Saat ini, hidupan liar ini masih sering diburu sehingga dikawatirkan populasinya akan terus menurun. Oleh sebab itu berbagai informasi sangat diperlukan untuk mendukung kegiatan konservasi secara in-situ maupun ex-situ terhadap ayam hutan hijau.

Populasi kecil dan fragmentasi habitat yang terjadi pada populasi ayam hutan hijau di Jawa dan Nusa Tenggara dapat meningkatkan laju genetic drift, kecenderungan terjadi kawin silang dalam (inbreeding), dan mengakibatkan terputusnya aliran gen (gene flow). Sebagai indikator adalah terjadi penurunan tingkat heterozigositas. Pada akhirnya, penurunan variabilitas genetik dapat membahayakan kelangsungan hidup populasi karena dapat mengurangi kemampuan dalam menghadapi tekanan seleksi alamiah, terutama akibat perubahan lingkungan (Lande dan Barrowclough, 1987; Avise, 1994; Hartl, 2000; Hedrick, 2000).

Perkembangan teknologi molekuler saat ini telah meningkatkan efisiensi dan akurasi dalam studi tentang berbagai keperluan (Vignal et al., 2002), antara lain studi untuk mengamati struktur populasi. Analisis DNA merupakan indikator yang lebih akurat untuk melihat dinamika dan struktur populasi dari hidupan liar (Avise et al., 1987; Hisheh et al., 1998). Studi tentang kajian DNA molekuler terhadap berbagai populasi ayam sudah banyak dilakukan. Hal ini disebabkan bahwa penanda genetik dapat memperlihatkan polimorfisme pada tingkat DNA. Oka et al., (2004) telah melakukan penelitian distribusi subspesies Gallus gallus (red jungle fowl / ayam hutan merah) dengan menggunakan D-loop DNA mitokondria. Hasil penelitian ini telah dapat memetakan berbagai subspesies ayam hutan merah dari wilayah Asia Selatan hingga Asia Tenggara. Penanda genetik yang sama digunakan Niu et al., (2002) mendeterminasi keragaman genetik ayam domestikasi di China. Selain itu, hasil penelitian Fumihito et al., (1994 dan 1996) membuktikan bahwa populasi ayam domestikasi di dunia adalah berasal dari satu nenek moyang (ancestor) yaitu ayam hutan merah (Gallus gallus gallus) yang berasal dari Asia Tenggara. Liu et al., (2006) menggunakan sekuen hypervariable-1 D-loop DNA mitokondria dalam penelitian filogeografi ayam di Asia Tenggara dan China. Kemudian Sulandari et al., (2006) telah berhasil menggunakan sekuen hypervarible-1 D-loop DNA mitokondria untuk menelusur asal usul ayam lokal Indonesia dengan memanfaatkan 15 breed (rumpun) ayam lokal dan ayam kampung dari berbagai daerah di Indonesia.

Namun sampai saat ini belum ada penelitian tentang kajian ayam hutan hijau secara molekuler. Tujuan penelitian ini ialah untuk mengamati distribusi haplotipe dan aliran gen ayam hutan hijau populasi di Jawa Tengah, Jawa Timur, Sumbawa, dan Flores, dengan menggunakan hypervariable-1 (HV-1) D-loop DNA mitokondria. Diharapkan distribusi haplotipe dapat memberikan gambaran aliran gen yang terjadi dari populasi tersebut, sehingga dapat memperlihatkan hubungan geneologi dari populasi yang diamati. Selain itu diversitas genetik populasi ayam hutan hijau merupakan informasi yang penting dalam usaha melakukan konservasi terhadap hidupan liar tersebut, serta dapat digunakan sebagai prediksi keadaan populasinya di alam.

\section{Metode Penelitian}

\section{Materi DNA ayam hutan hijau}

Materi DNA yang digunakan adalah darah yang diawetkan dengan menggunakan $100 \%$ alkohol. Sejumlah 33 sampel darah ayam hutan hijau (Gallus varius) yang digunakan untuk analisa dalam penelitian ini dikoleksi dari Flores (12 sampel), Sumbawa (3 sampel), Jawa Timur (4 sampel), dan Jawa Tengah (14 sampel). 


\section{Ekstraksi DNA dan amplifikasi PCR}

Ekstraksi DNA total dan amplifikasi PCR dilakukan di Laboratorium Genetika, Bidang Zoologi, Pusat Penelitian Biologi-LIPI. Ekstraksi DNA dilakukan mengikuti metoda yang dikembangkan oleh Sambrook et al., (1989). Hasil ekstraksi yang berupa DNA total diamati secara kualitatif dengan proses elektroforesis pada gel agarose $1 \%$. Sedangkan pemeriksaan secara kuantitatif dilakukan dengan cara menghitung konsentrasi DNA total menggunakan mesin spektrofotometer.

Amplifikasi segmen HV-1 D-loop DNA mitokondria dilakukan dengan metode Polymerase Chain Reaction (PCR) menggunakan Thermal Cycler Applied Biosystems Type 2700. Adapun amplifikasi fragmen D-loop dengan menggunakan primer universal dengan sekuen sebagai berikut:

\section{L16750 (forward): 5'-AGGACTACGGCTTG AAAAGC-3' \\ CR1b (reverse): 5'-CCATACACGCAAACCG TCTC-3'}

Kondisi PCR yang dipakai adalah predenaturasi $94^{\circ} \mathrm{C}$ selama 5 menit, kemudian denaturasi $94^{\circ} \mathrm{C}$ selama 45 detik, annealing pada temperatur $60^{\circ} \mathrm{C}$ selama 45 detik dan elongasi pada temperatur $72^{\circ} \mathrm{C}$ selama 90 detik, dengan siklus sebanyak 30 kali, kemudian dilanjutkan dengan final ekstension $72^{\circ} \mathrm{C}$ selama 10 menit. Visualisasi hasil PCR dilakukan dengan proses elektroforesis pada gel agarose $2 \%$.

\section{Sekuensing segmen HV1 D-loop}

Analisis sekuen dari segmen HV1 Dloop genom DNA mitokondria dilakukan di Laboratorium International Livestock Research Institute (ILRI), Nairobi, Kenya dengan menggunakan 3100 genetic analyser (ABI Prism). Produk PCR yang telah dipurifikasi, disekuen untuk mengetahui urutan nukleotida. Amplifikasi segmen HV1 D-loop dengan menggunakan 1 set internal primer sekuensing, yaitu CR-forward 5'-TCT ATA TTC CAC ATT TCT C-3' dan CR-reverse 5'-GCG AGC ATA ACC AAA TGG-3'. Kit sekuensing yang digunakan adalah BigDye*Terminator Version 3.1 (Applied Biosystems) dengan total volume
$20 \mu \mathrm{l}$ yang mengandung $20 \mathrm{ng}$ produk PCR yang telah dipurifikasi sebagai template DNA dan 3.2 pmol primer. Pada setiap tabung reaksi PCR berisi $8 \mu \mathrm{l}$ Big Dye terminator ready reaction mix (campuran dNTP, ddNTP, bufer, enzim, dan $\mathrm{MgCl}_{2}$ ), $8 \mu \mathrm{l}$ air milliQ, $2 \mu \mathrm{l}$ masing-masing primer CR-forward atau CRreverse, dan $2 \mu$ template DNA. Kemudian tabung divortex sebentar dan disentrifugasi selama 10 detik. Selanjutnya dilakukan reaksi sekuen di mesin PCR (Thermal Cycler Applied Biosystems type 9700). Kondisi PCR untuk reaksi sekuen adalah $96^{\circ} \mathrm{C}$ selama 10 detik, $50^{\circ} \mathrm{C}$ selama 5 detik, dan $60^{\circ} \mathrm{C}$ selama 4 menit sebanyak 25 siklus. Setelah proses selesai, reaksi sekuen disimpan pada temperatur $4^{\circ} \mathrm{C}$ sampai siap di purifikasi dengan menggunakan AMPure*PCR purification kit (Agencourt Bioscience Corporation, 500 Cummings Center, Beverly, MA). Purifikasi dilakukan untuk menghilangkan kelebihan primer, nukleotida, dye-terminator, garam, dan enzim. Selanjutnya di sekuen dengan menggunakan 3100 genetic analyser (ABI Prism).

\section{Analisis data molekuler}

Sekuen segmen HV-1 D-loop genom DNA mitokondria sepanjang 397 bp digunakan untuk analisa dalam penelitian ini. Data sekuen dianalisis dengan menggunakan berbagai macam komputer software. Chromas versi 1.45 digunakan untuk viewing dan editing hasil sekuen. BioEdit versi 7.0.1. digunakan untuk menselaraskan sekuen forward dan reverse. Multiple alignment sekuen dilakukan dengan menggunakan program ClustalX 1.83. Sedangkan untuk analisis filogenetik digunakan dengan metoda neighbor-joining, dimana kalkulasi matrik jarak genetik dengan model Kimura-2 parameter yang diimplementasikan pada pairwise distance calculation dalam program MEGA (Molecular Evolutionary Genetics Analysis) software Versi 3.1 (Kumar et al., 2004). Estimasi variasi sekuen DNA di dalam populasi dan antar populasi, keragaman haplotipe (haplotype diversity), dan keragaman nukleotida (nucleotide diversity) serta Fu's dan Li's test menggunakan DNA Sequence Polymorphisme (DnaSP) versi 4.00. 


\section{Hasil dan Pembahasan}

\section{Struktur genetik populasi ayam hutan hijau}

Sekuen segmen HV-1 D-loop dari genom DNA mitokondria digunakan dalam melihat struktur genetik dari populasi 33-individu ayam hutan hijau. Hasil sekuen dari 33 individu ayam hutan hijau diperoleh (33 sekuen forward dan 33 sekuen reverse) dan diselaraskan dengan referensi GenBank (kode/nomer akses D64163) dengan menggunakan program CLUSTALX Version 1.83.

Pengamatan sekuen HV1 D-loop ayam hutan hijau sepanjang 397 urutan basa dilakukan terhadap masing-masing sekuen dari total 33 sekuen yang diperoleh: 14 sekuen (Jawa Tengah), 4 sekuen (Jawa Timur), 3 sekuen (Sumbawa), 12 sekuen (Flores). Hasil pengamatan ditemukan 28 situs polimorfik (variable site) dan terdapat 25 tipe sekuen (haplotipe), yaitu haplotipe A, B, C, D, E, F, G, H, I, J, K, L, M, N, O, P, Q, R, S, T, U, V, W, $\mathrm{X}$, dan Y (Tabel 1). Sebaran haplotipe tersebut adalah ditemukan 13 haplotipe (B, L, M, N, O, P, Q, R, S, T, U, V, dan W) di Jawa Tengah, 3 haplotipe (H, I, dan J) di Jawa Timur, 2 haplotipe (B dan K) di Sumabawa, dan 9 haplotipe (A, B, C, D, E, F, G, X, dan Y) di Flores. Hasil analisis menunjukkan bahwa nilai Fu's Fs adalah -25,96 (semua sampel, $\mathrm{P}=0$ ). Hal ini merupakan indikasi terdapat keragaman genetik (genetic diversity) dan perluasan populasi (population expansion) ayam hutan hijau yang tinggi.

Keragaman haplotipe (haplotype diversity) tertinggi ditemukan di Jawa Tengah $(0,981 \pm 0,031)$, selanjutnya di Jawa Timur $(0,900 \pm 0,161)$, Flores $(0,885 \pm 0,070)$, dan Sumbawa $\quad(0,833 \pm 0,222)$ Keragaman nukleotida (nucleotide diversity) yang tertinggi adalah Jawa Tengah $(0,01267)$, selanjutnya Sumbawa $(0,00640)$, Jawa Timur $(0,00606)$, dan Flores (0,00602). Keuntungan dengan menggunakan parameter keragaman nukleotida adalah tidak tergantung pada besarnya sampel dan panjang DNA (Hartl dan Clark, 1989). Frekuensi haplotipe yang diperoleh menunjukkan hasil yang sama, yaitu 0,03. Sedangkan frekuensi haplotipe yang berbeda adalah haplotipe B $(0,15)$, serta haplotipe $C$ dan D $(0,06)$.

Hasil analisis yang menunjukkan bahwa 25 haplotipe yang teridentifikasi pada 28 situs polimorfik (polymorphic site/variable site) dan distribusi variasi sekuen dapat dilihat pada Tabel 1 dan histogram pada Gambar 1. Distribusi variasi sekuen yang dihasilkan dari penelitian ini adalah pada urutan basa antara 049 (3\%), 50-99 (0\%), 100-149 (7\%), 150-199 (7\%), 200-249 (43\%), 250-299 (7\%), 300-349 (21\%), dan 350-399 (11\%). Terlihat bahwa situs polimorfik pada segmen $\mathrm{HV}-1$ yang tertinggi terdapat pada urutan DNA 200 hingga 249, yaitu 43\%. Dengan demikian dapat dikatakan bahwa sekuen ayam hutan hijau mempunyai variabilitas yang tinggi pada nukleotida antara 200 - 397 (83\%), sedangkan pada 200 panjang nukleotida pertama hanya memberikan $17 \%$ variasi sekuen. Posisi ini sama dengan hasil analisis terhadap ayam lokal Indonesia (Sulandari et al., 2006).

\section{Hubungan kekeluargaan}

Rekonstruksi pohon filogeni populasi ayam hutan hijau ini dilakukan berdasarkan urutan nukleotida segmen hypervariable-1 Dloop dari genom DNA mitokondria. Segmen ini memiliki kecepatan evolusi yang tinggi dibanding daerah lainnya (Taberlet, 1996), sehingga segmen ini lebih banyak situs polimorfik yang berguna dalam rekonstruksi pohon filogeni intraspesifik. Pohon filogeni ini menggunakan metoda Neighbor-joining yang termasuk dalam metoda jarak yang didasari pada prinsip pengelompokkan taksa berdasarkan nilai jarak evolusioner pasanganpasangan operational taxonomy unit dimana setiap percabangan yang terdapat dalam pohon filogeni berevolusi pada kecepatan yang tidak sama (Hartl, 2000). 
Tabel 1. Polimorfisme nukleotida yang di analisa pada segmen HVI D-loop DNA mitokondria, diselaraskan dengan referensi GenBank (kode/nomer akses D64163).

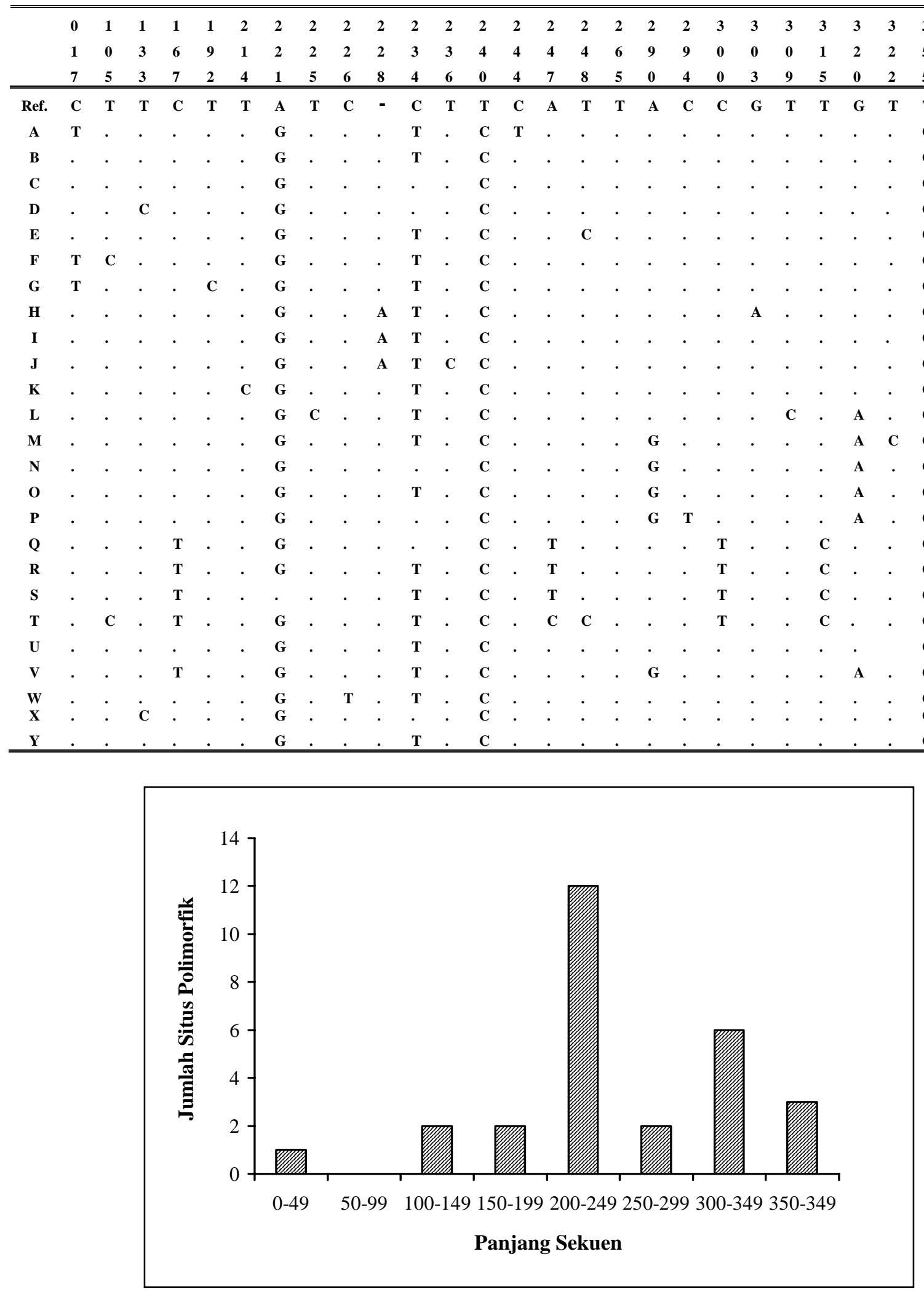

Gambar 1. Distribusi variasi sekuen pada segmen hypervariable-1 D-loop DNA mitokondria. 
Jarak genetik sebagai dasar rekonstruksi pohon filogeni berdasarkan 25 haplotipe yang berhasil diidentifikasi, yaitu berkisar antara 0,0 - 0,023 (Lampiran 1). Jarak genetik dari masing-masing populasi dan hasil analisis hubungan kekeluargaan diantara populasi ayam hutan hijau yang berasal dari Jawa Tengah, Jawa Timur, Sumbawa, dan Flores dapat dilihat pada rekonstruksi pohon filogeni (Gambar 2). Sampel bervariasi antara 3 hingga 14, sedang nilai Fs dari 4 populasi tersebut antara $-2,20$ dan $-10,76$ (berbeda nyata, $\mathrm{P}=0$ ). Hanya satu haplotipe, yaitu haplotipe B yang terdapat di tiga populasi Jawa Tengah, Sumbawa, dan Flores. Selain itu semua haplotipe terdiri hanya satu individu, kecuali haplotipe B, C, dan D yang terdiri dari 2 individu. Hal ini menunjukkan bahwa haplotipe dari populasi ayam hutan hijau ini sangat unik. Indikator perbedaan genetik diantara populasi tersebut dikonfirmasikan dengan nilai Fst $(\mathrm{P}=0,5)$ yang berbeda nyata antara populasi ayam hutan hijau di Jawa Tengah, Jawa Timur, Sumbawa, dan Flores.

Hasil pohon filogeni memperlihatkan bahwa dari empat populasi ayam hutan hijau tersebut terbentuk 5 kelompok yang mempunyai hubungan kekerabatan dekat, yaitu kelompok pertama terdiri dari haplotipe J (Jawa Timur), Y (Flores), K (Sumbawa), I (Jawa Timur), B (Jawa Tengah, Sumbawa, Flores), U (Jawa Tengah), dan H (Jawa Timur). Hasil analisis memperlihatkan kelompok ini mempunyai kaitan hubungan kekerabatan dekat dengan semua populasi yang diteliti. Haplotipe B yang terdapat di Jawa Tengah, Sumbawa, dan Flores juga berada dalam kelompok ini. Selain itu, ada fenomena yang menarik dimana semua individu dari populasi Jawa Timur berada di kelompok ini dan berasosiasi dengan haplotipe dari semua populasi yang diteliti. Komposisi demikian memperlihatkan bahwa populasi di Jawa Timur berkaitan erat dengan populasi ayam hutan hijau lainnya. Hal ini sebagai indikator kemungkinan pusat sebaran ayam hutan hijau berada di wilayah ini.

Kelompok kedua terdiri hanya individu yang berasal dari Jawa Tengah, yaitu haplotipe $\mathrm{N}, \mathrm{P}, \mathrm{V}, \mathrm{M}$, dan O. Kelompok ketiga terdiri dari individu dari Flores yaitu haplotipe F, A, dan G. Kelompok keempat terdiri individu dari Flores, yaitu haplotipe E, C, D, dan X serta haplotipe dari GenBank (kode akses D82912). Kelompok kelima terdiri dari individu berasal dari Jawa Tengah, yaitu haplotipe N, P, V, M, dan O. Sedangkan haplotipe $\mathrm{L}$ dari populasi Jawa Tengah membentuk clade sendiri. Haplotipe L adalah ayam bekisar, yaitu hasil silang antara ayam hutan hijau dengan ayam kampung.

Diversitas genetik yang tinggi dengan muncul 28 situs polimorfik yang terdiri dari 25 haplotipe (tipe sekuen) merupakan fenomena yang unik. Diduga berhubungan dengan adanya perbedaan silsilah yang berasosiasi dengan kondisi lingkungan setempat yang menyebabkan adanya individu-individu yang berkembang pada populasi di habitat yang terisolasi oleh fragmentasi habitat sehingga tidak menyebar ke tempat lain. Kemungkinan lain yang dapat diduga adalah baru terjadinya mutasi pada situs yang polimorfik tersebut, sehingga penyebaran haplotipe sangat terbatas. Hal ini ditunjukkan hanya haplotipe $B$ yang terdapat pada tiga populasi yang diteliti. Sebagaimana diketahui bahwa DNA mitokondria diturunkan secara maternal (Nei, 1987). Dengan demikian populasi ayam hutan hijau ini memperlihatkan fenomena adanya isolasi yang ditunjukkan dengan penyebaran haplotipe yang rendah dan tidak merata, walaupun keragaman haplotipe cukup tinggi. Fenomena ini sering dijumpai pada jenis hewan terbang yang memiliki daerah sebaran luas (Avise et al., 1987).

Habitat ayam hutan hijau saat ini sudah terfragmentasi oleh kepentingan manusia, selain itu habitatnya yang tersebar diberbagai pulau juga memiliki isolasi geografis seperti laut yang mengakibatkan terputusnya aliran gen. Storz (2002) melakukan pengamatan terhadap bentuk variasi genetik mikrosatelit pada kelelawar pemakan buah di India, menunjukkan adanya hubungan yang positip antara jarak genetik dan faktor geografi (isolation by distance) antar populasi. Selain itu, populasi yang terisolasi biasanya mempunyai jumlah anggota kecil (Schmitt, 1978). Oleh sebab itu diperlukan informasi keragaman genetik untuk memberikan gambaran yang jelas dari berbagai populasi yang ada sebagai dasar tindakan konservasi yang diperlukan. 


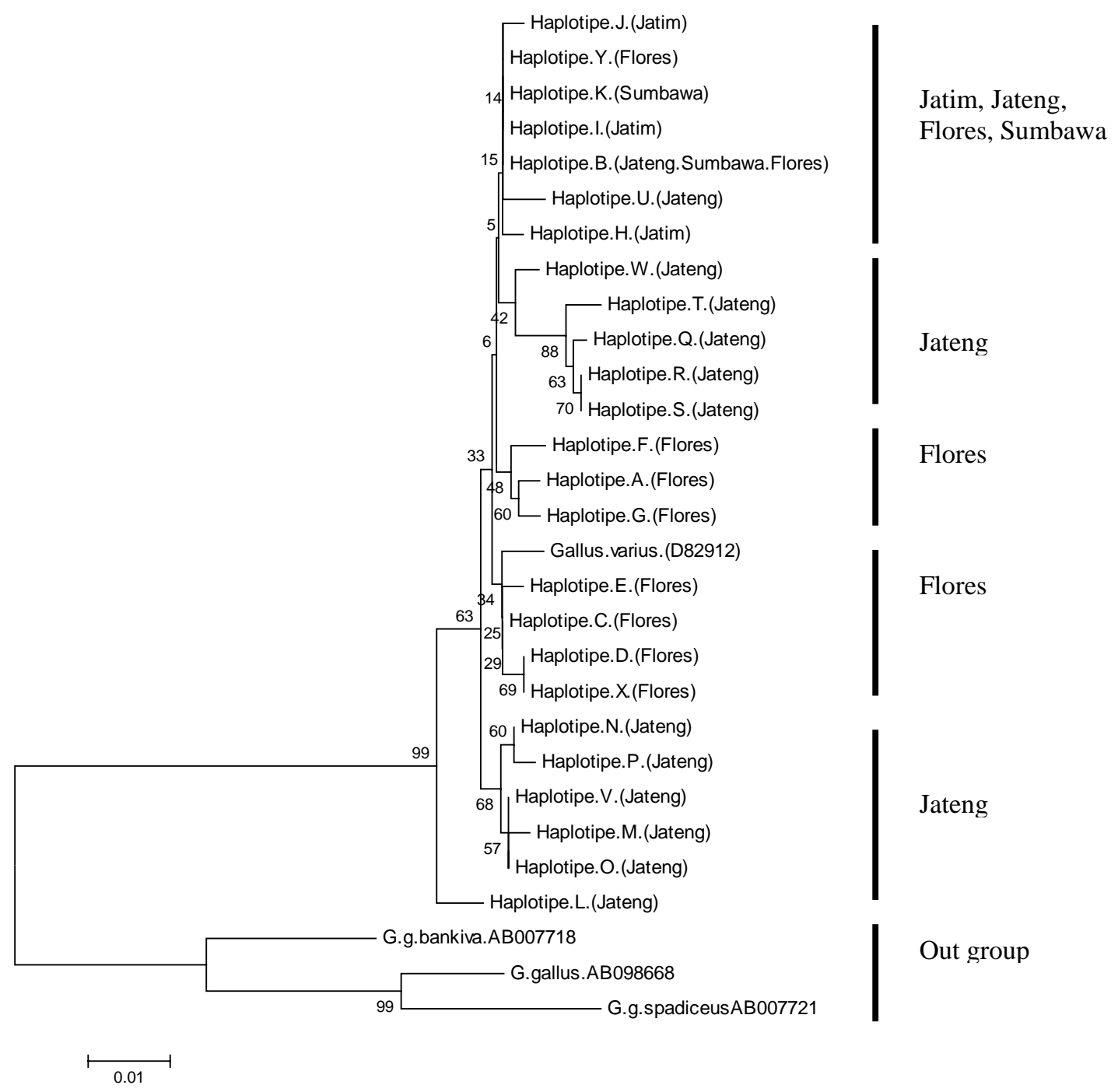

Gambar 2. Rekonstruksi pohon filogeni ayam hutan hijau (Gallus varius) dari haplotipe A-W yang dibuat dengan metoda Neighbor-joining menggunakan Software MEGA versi 3.1, sedangkan ayam hutan merah (G.g. bankiva (AB007718), Gallus gallus (AB098668), dan G.g. spadiceus (AB007721) digunakan sebagai outgroup.

\section{Kesimpulan dan Saran}

\section{Kesimpulan}

Hasil kajian diketahui ayam hutan hijau di Jawa Tengah, Jawa Timur, Sumbawa, dan Flores memiliki keragaman genetik tinggi. Namun demikian populasi ayam hutan hijau memperlihatkan fenomena adanya isolasi yang ditunjukkan dengan penyebaran haplotipe yang rendah dan tidak merata. Hal ini akibat terjadi fragmentasi habitat dan rintangan alam (natural barrier) sehingga terputusnya aliran gen diantara populasi.

\section{Saran}

Perlu dilakukan tindakan konservasi di setiap habitat ayam hutan dan menjaga kelestarian lingkungannya karena masing masing habitat memiliki keragaman genetik yang berbeda dengan populasi dari habitat lainnya. 


\section{Daftar Pustaka}

Avise, J.C., Arnold, J., Ball, R.M., Bermingham, E., Lamb, T., Neigel, J.E., Reeb, C.A. and Saunders, N.C. 1987. Intraspecific phylogeography: the mitochondrial DNA bridge between population genetics and systematics. Ann. Rev. Ecol. and Syst. 18: 489-522.

Avise, J.C. 1994. Molecular markers, Natural History and Evolution. Chapman and Hall, New York.

Fumihito, A., Miyake, T., Sumi, S., Takada, M., Ohno, S. and Kondo, N. 1994. One subspecies of the red jungle fowl (Gallus gallus gallus) suffices as the matriarchic ancestor of all domestic breeds. Proc. Natl. Acad. Sci. USA. 91: 12505-12509.

Fumihito, A., Miyake, T., Takada, M., Shingu, R., Endo, T., Gojobori, T., Kondo, N. and Ohno, S. 1996. Monophyletic origin and unique dispersal patterns of domestic fowls. Proc. Natl. Acad. Sci. USA. 93: 6792-6795.

Hartl, D. 2000. A primer of population genetics. 3rd ed. Sinauer Associates, Inc., Sunderland.

Hartl, D.L. and Clark, A.G. 1989. Principles of Population Genetics, $2^{\text {nd }}$ ed. Sinauer Associates, Massachusetts.

Hedrick, P.W. 2000. Genetics of populations. 2nd ed. Jones and Bartlett Publishers, Sudbury.

Hisheh, S., Westerman, M. and Schmitt, L.H. 1998. Biogeography of the Indonesian Archipelago: mitochondrial DNA variation in the fruit bat, Eonycteris spelaea. J. Linn. Soc. 65:329-345.

Kumar, S., Tamara, K. and Nei, M. 2004. Mega3: Integrated software for molecular Evolutionar genetics analysis and sequence alignment. Briefings in Bioinformatics. Henry Stewart publication. 5 (2): 150-163.

Lande, R. and Barrowclough, G.F. 1987. Effective population size, genetic variation, and their use in population management. In: Soule, M.E. (Eds.). Viable population for conservation. Cambridge University Press, Cambridge: 87123.

Liu, Y.P., Wu, G.S., Yao, Y.G., Miao, Y.W., Luikart, G., Baig, M., Pereira, A.B., Ding, Z.L., Palanichamy, M.G. and Zhang, Y.P. 2006. Multiple maternal origin of chickens: Out of the Asian jungles. Molecular Phylogenetics and Evolution.38: 12-19.
Niu, D., Fu, Y., Luo, J., Ruan, H., Yu, X.P., Chen, G. and Zhang, Y.P. 2002. The origin and genetic diversity of Chinese native chicken breeds. Biochem. Genet. 40: 163-174.

Oka, T., Amano, T., Hayashi, Y. and Fumihito, A. 2004. Philological Studies on Subspecific Recognition and Distribution of Red Junglefowl. J. Yamashita Inst. Ornithol. 35: 77-87.

Sambrook, J., Fritsch, E.F. and Maniatis, T. 1989. Molecular Cloning, A Laboratory Manual. $2^{\text {nd }}$ Edition. Cold Spring Harbor Laboratory Press.

Schmitt, L.H. 1978. Genetic variation in isolated populations of the Australian bush-rat, Rattus fuscipes. Evolution 32: 1-14.

Sibley, C.G. and Monroe, B.L. 1990. Distribution and Taxonomy of Birds of the World. Yale University Press. New Haven \& London.

Storz, J.F. 2002. Contrasting patterns of divergence in quantitative traits and neutral DNA markers: analysis of clinal variation. Molecular Ecology 11 (12):2537-2551.

Sulandari, S., Zein, M.S.A., Sartike, T., Paryanti, S. dan Kundarmasno, A. 2006. Karakterisasi Molekuler Ayam Lokal Indonesia. Laporan Kegiatan Riset Kompetitif LIPI Tahun Anggaran 2005-2006, Program Penelitian dan Pengembangan IPTEK-LIPI.

Taberlet, P. 1996. The use of mitochondrial DNA control region sequencing in conservation genetics. In: Smith, T.B. and Wayne, R.K. (Eds.). Molecular genetic approaches in conservation. Oxford University Press, New York: 125-142.

Vignal, A., Milan, D., Cristobal, M.S. and Eggen, A. 2002. A review on SNP and other type of Molecular markers and their use in animal genetics. Genet. Sel. Evol. 34: 275-305.

Wirdateti, Sumiyarni, N., Anita, S.T. dan Didit, D. 2007. Aktivitas yang berhubungan dengan pola konsumsi pakan Tarsius (Tarsius bancanus) di penangkaran pada malam hari. Biota 12 (3): 153-160. 
Lampiran 1. Estimasi matrik jarak genetik haplotipe ayam hutan hijau (Gallus varius) dari Jateng, Jatim, Sumbawa, dan Flores

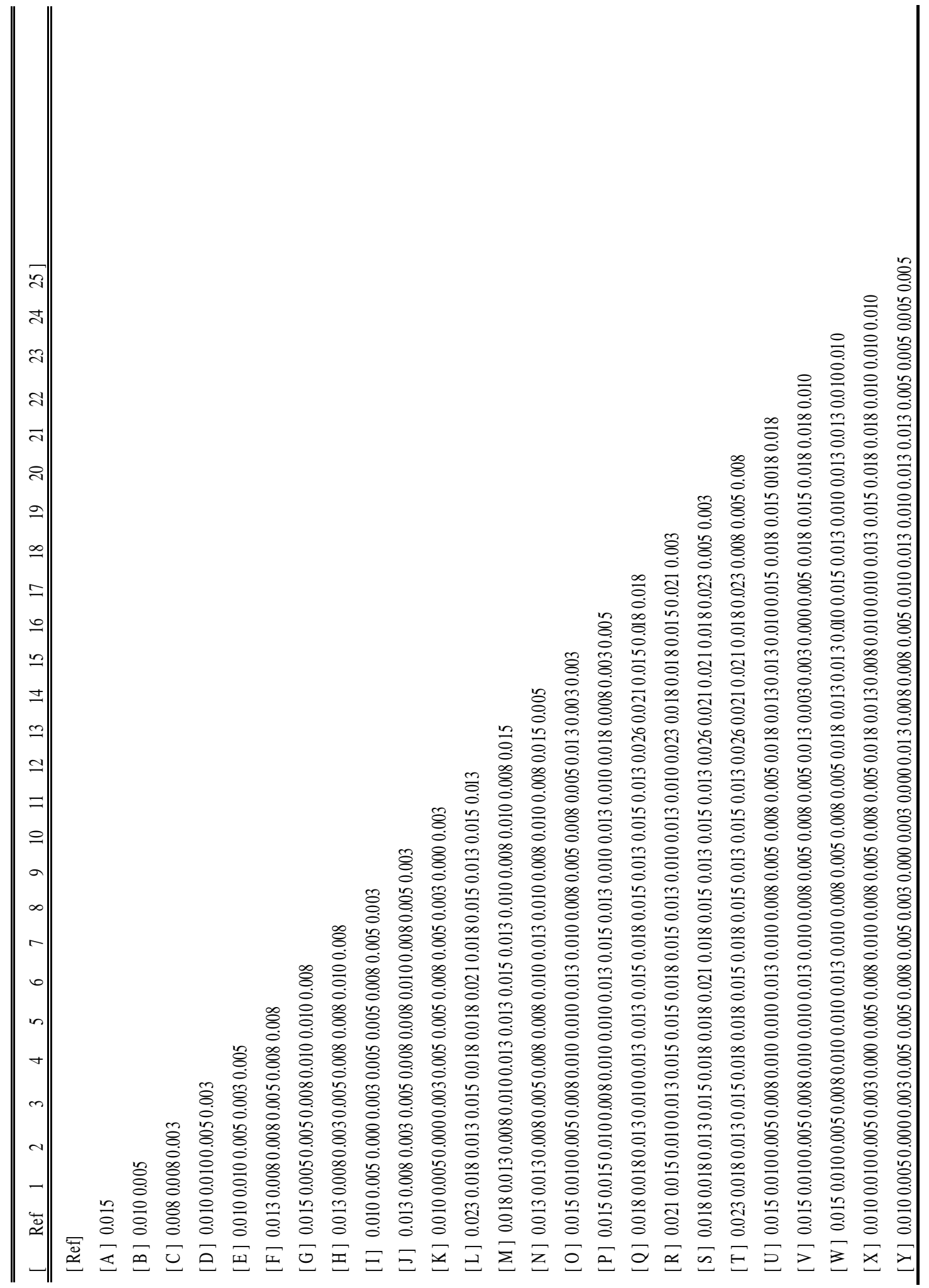

